\title{
The Profile Of Disaster Mitigation Literacy Ability By Students In The School Prone To Tidal Floods
}

\author{
Dwi Putri Meliana ${ }^{1}$, Erni Suharini ${ }^{2}$, Tjaturahono Budi Sanjoto ${ }^{3}$ \\ \{dwip.meliana@gmail.com¹, erni.suharini@mail.unnes.ac.id², tjatur@mail.unnes.ac.id ${ }^{3}$ \} \\ Graduate School, Universitas Negeri Semarang, Indonesia
}

\begin{abstract}
A Tidal flood becoming a serious threat in the coastal area. A School is a source of knowledge, dissemination of science disasters. Therefore, students' disaster mitigation literacy skills are very important. The aim of this study is to analyze the profile of students' disaster mitigation literacy abilities in the schools prone to tidal floods. The research method used is the pre-experimental method using one shoot test design. This research has been done in SMA Negeri 10 Semarang. The result of this study shown that students disaster mitigation literacy abilities were at level 1 which is as much as $33.3 \%$. The components of the PISA assessment used included the components of the process, concepts, contexts and attitudes of students towards disaster mitigation. The results of this study can be an initial reference for the preparation of enrichment materials in improving awareness of disasters for school residents.
\end{abstract}

Key words: Disaster Mitigation Literacy, Disaster Prone Schools, Tidal Floods

\section{Introduction}

The city of Semarang is one of the major cities in Indonesia and the capital of Central Java. Some sub-districts are located in the north coast of Java also located along the direction of the river of Semarang, where these sub-districts are often flooded ${ }^{[1]}$. The city of Semarang has a tidal flooding problem of environmental damage caused by the inundation tidal floods. This is because the Semarang city has a relatively flat contour that complicity drainage in supplying water to urban areas, especially during high tide ${ }^{[2]}$. The options to deal with disaster is mitigation strategy by communicating disaster risks to vulnerable community ${ }^{[3]}$. The term "mitigation programs" refers to two stages of planning: pre-event planning for disaster management, which includes disaster mitigation and planning activities and post-event planning and actions, including rebuilding of damaged infrastructure, city re-planning, improvement of technical standards, and medical and financial aid to victims ${ }^{[4]}$. One of the public facilities affected by tidal floods is school. The school is a formal educational institution that plays a role in shaping the character and knowledge of students through daily learning activities. Tidal floods which hit schools causes learning activities to be disrupted ${ }^{[5]}$.

In the Semarang city schools that are in vulnerable area of tidal floods, one of them is SMA N 10 Semarang that located in Genuk Sub-district. This school has the potential to be used as a model against for efforts to disaster mitigation. Based on the results of observations, SMA N 10 Semarang is a school that is often exposed to flooding because of tides. SMA N 10 Semarang is directly affected by tidal floods because its location is close to the north coast of 
Java and has a morphological condition in the form of an alluvial plain with a low slope that makes the area vulnerable to flooding.

In view of potential disasters above, there is an effort to preparedness, early warning and disaster mitigation [6]. Disaster education, specific subfield of Education in Emergency has become a main subject of interest in teaching and learning science also due to the apparent increase in natural disasters occurred over the last century [7]. While the field of Education in Emergency has expanded in the last decade, research on education and natural disasters is still in its infancy [8]. Nowadays, awareness and public understanding of the various types of disaster that often occur in the vicinity are still very low. Many evidences, in fact, demonstrate that, during a natural disaster, misconceptions as well as incorrect beliefs may lead to inadequate behaviour [9]. Meanwhile, disaster education programs that have been running are still not comprehensive touching all society elements and institutional elements. As an example of formal education element has not significantly involved in disaster mitigation efforts [10].

Current conditions of disaster education in Indonesia are: (1) The lack of knowledge and understanding of teachers regarding knowledge of disaster risk reduction; (2) The lack of guidance, syllabus, and teaching materials that are distributed and accessible to teachers and education actors, thus causing the teacher's lack of capacity and expertise in integrating DRR, or Disaster risk reduction, into the curriculum; and (3) the vulnerability of physical conditions, facilities and school infrastructure to disasters ${ }^{[11]}$. In addition, the disaster mitigation material contained in the textbook is still explained in general as an example of flood material, even though in some regions, especially in the coastal areas of Indonesia there is a threat of flooding that occurs due to tides ${ }^{[12]}$. This material can be provided through material substance that is integrated with the school curriculum so that students have an understanding of disaster risk reduction efforts.

All kinds of disruption of school activities because of tides will cause social change for schools that undergoes them. These social changes require schools in tides prone areas to be able to adapt itself to the situation. Tides occurring require schools in tides prone areas to have an attitude and strategy to do at the time before and after a disaster. Given the fact that schools vulnerable to floods, schools should begun to formulate disaster mitigation strategies in accordance with their respective needs, so that when the disaster arises from tides arrival, they are ready to anticipate so as to minimize the impact of losses.

Based on the explanation above, there must be integrated disaster mitigation literacy in learning. Literacy learning is the development of abilities and activities based on scientific knowledge relevant to daily life and career in decision making for tidal flooding problem solving [13], the main purpose of using literacy strategies in learning is to build student understanding, writing skills, and communication skills thoroughly. School readiness in dealing with disasters is also part of Disaster risk reduction (DRR) Efforts in the 2005 - 2015 Hyogo Framework for Action which forms the basis of international DRR ${ }^{[14]}$. It is strange given that consideration of both actual and potential hazards/disasters can elicit strong emotions in the learner: learning that a disaster once ravaged one's community and that there might be a recurrence can be frightening, if not nightmarish unless pre-emptive steps are taken [15]. The narrative is a privileged method that can help developing cognitive skills, organize knowledge and support the construction of meaning ${ }^{[16]}$.

Schools in the prone areas of tides have the potential and flood threats are high that scientific literacy can be used to overcome tidal flooding problems. Literacy in the context of learning is related to disaster expenditure planning. This is done in mitigating disaster situations ${ }^{[17]}$. So that disaster mitigation literacy is a part of scientific literacy because 
working together is to make a mindset, behavior and build a human character to care and be responsible for oneself, society and the universe, and help those who help in society.

Thus literacy strategies in learning will form the characteristics of students and develop $21^{\text {st }}$ century skills (Higher Order Thinking Skills) it is also in line with the opinion of Mahardika et al ${ }^{[18]}$ who say that literacy plays an important role in facing the challenges of the $21^{\text {st }}$ century, because in various activities require scientific information for use as consideration in carrying out daily life. According to Archer-Bradshaw [19], producing individuals who have literacy skills is very important to prepare for their future so that students are able to adapt to social life that can change rapidly.

Based on explanation above, the purpose of this paper is to analyze the literacy profile of students regarding disaster mitigation for class XI students at SMA N 10 Semarang. The disaster mitigation literacy profile is used as a tidal flooding problem solving effort. Disaster mitigation literacy is a step to prepare themselves in facing disaster risk.

\section{Methods}

The research method used is the pre-experimental method using one shoot test design. The technique of sampling is by using purposive sampling technique, because: 1) students use the same learning resource book; 2) students get material based on the same curriculum; 3) students become the object of research sitting at the same class level; 4) class division is not based on ranking. The data collection used with the test, questionnaire, and documentation. Data collection in this study was carried out using literacy instruments consisting of four literacy questions of process, concept, context and attitude [20]. This study was conducted on 36 students of class XI IPS 1 at SMAN 10 Semarang as a school in the area prone to tidal floods. The research data is in the form of students' answers related to four literacy questions which are assessed by researchers using the rubric with a scale of $0-4$. The answers given by students are then interpreted according to the research tidal flooding problems. The research data analysis uses descriptive analysis [21].

\section{Results and Discussions}

\subsection{Disaster Mitigation Literacy Capability Profile}

Disaster mitigation literacy is the ability to deal with disaster threats through a set of knowledge covering all aspects needed as an effort to increase disaster risk reduction. The profile of students' disaster mitigation literacy abilities can be seen in table 1 .

Table 1. Students' Disaster Mitigation Literacy Capability Profile

\begin{tabular}{ccc}
\hline & Value Group & \\
Level & Skor & Precentage (\%) \\
\hline 6 & 708 & 0 \\
5 & 633 & 8.33 \\
4 & 559 & 27.7 \\
3 & 484 & 19.4 \\
2 & 410 & 11.1 \\
1 & 335 & 33.3 \\
\hline
\end{tabular}


The data in table 1 shows that the disaster mitigation literacy abilities of students in schools prone tidal floods in Semarang High School are mostly in the level 1 which is as much as $33.3 \%$. One of the factors supporting the level of literacy mitigation for students is the experience of students in the event of a disaster. For students who attend schools in the vicinity of the disaster will be more familiar with disasters because they are accustomed to disasters. School prone tidal flood is a school that is often exposed to flooding because of tides. Tidal flood which occurs in schools on average inundations as high as $0-70 \mathrm{~cm}$ with the intensity of the appearance of tidal floods in the morning and evening (daily tidal floods type mixture tends to double or mixed semidiurnal). The peak of tidal floods inundation that occurs in April-May is approaching the transition period.

Another factor that can also cause differences in values obtained is the lack of disasterrelated information to students. Minimal experience and lack of disaster material information. This tidal flooding problem can be solved in several ways; through field assignment, reading assignments and finding relevant information or conducting field studies to the location of disasters at the time of a disaster. Obtaining direct information by students through disaster observation will be a stronger knowledge provision. Learners can see how the impact caused by flooding due to tides of the sea. The facts found in the field make learners can think more critically about the surrounding tidal flooding problems. Meanwhile, the implementation of learning that raises natural disaster phenomena around will make the learners become confident about the importance of science that is being studied. This will increase the level of student disaster mitigation literacy and provide a better and more firmly embedded value of learning.

The results of the study in table 1 also showed that the level of disaster mitigation literacy abilities of students varied. The distribution of values obtained by students is spread evenly into 6 groups. Generally based on the percentage most of the entries are in medium category this indicates that students are quite good at reasoning the phenomenon of natural disasters, except that it needs to be optimized so that good reasoning supplies can produce satisfactory results.

\subsection{Profile of Literacy on Disaster Mitigation Based on Literacy Aspects}

Literacy profiles can be shown based on the aspects of literacy. The results of data processing on the spread of students' abilities based on literacy aspects can be seen in table below.

Table 2. The spread of students' abilities based on Literacy Aspects

\begin{tabular}{ccc}
\hline Aspect & Value & Overall Percentage (\%) \\
\hline Process & 2.4 & 60.0 \\
Concept & 2.5 & 62.5 \\
Context & 3.0 & 75.0 \\
Attitude & 2.7 & 67.5 \\
Average & $\mathbf{2 . 6}$ & $\mathbf{6 6 . 2}$ \\
\hline
\end{tabular}

Based on the data in table 2, it appears that the majority of students have a score of 2 in each aspect of literacy. The knowledge aspect of the process becomes the least valued aspect of 2.4 , which is as much as $60 \%$, while for the concept aspect, the value of 2.5 is $62.5 \%$. The context aspect has a value of 3.0 as much as $75 \%$ and the attitude aspect gains 2.7 by $67.5 \%$. The number of student outcomes in the process aspect is also related to the ability to 
understand student concepts. The results of the students' answers analysis indicated that the majority of students were unable to tell in detail and clearly or described the process the occurrence of tidal flood from scientific perspective. However, the subjects in this study were more literate in disaster mitigation because there was a small portion of the subject group gaining values above 3 and the majority of subjects scored 2 in each aspect of literacy. This could be influenced by the interaction patterns of students with the environment. In addition, the frequency of disaster occurrence also affects the level of students' literacy related to the disaster. Students in schools prone tidal flood areas are used to facing floods. Most of the students have been able to adapt by always bring sandals to school when it rains before heavy rain. This is obtained by student themselves.

Students' disaster mitigation literacy profiles can also be analyzed based on the acquisition of the value of the subject group in answering questions related to scientific literacy. This can be used to identify which aspects still have a low value for later improvement in the future. The results of the analysis of the value of students based on each aspect are shown in table 3.

Table 3. Percentage of values in each aspect of literacy

\begin{tabular}{cccccc}
\hline \multirow{2}{*}{ Value } & \multicolumn{5}{c}{ Literacy Aspects } \\
& Process & Concept & Context & Attitude & \multirow{2}{*}{ Average \% } \\
\hline $0.0-1.0$ & 5 & 4 & 3 & 4 & 11.11 \\
$1.1-2.0$ & 17 & 9 & 8 & 10 & 30.6 \\
$2.1-3.0$ & 10 & 11 & 5 & 16 & 29.1 \\
$3.1-4.0$ & 4 & 12 & 20 & 6 & 29.1 \\
\hline
\end{tabular}

With regards to disaster mitigation studies, the research findings are still beyond expectation as students are essentially expected to provide reasonable reasoning for catasphoric phenomenon that have occur surrounding environment. This has not been seen in achieving students' values on the aspect of disaster mitigation literacy, which is in the process aspects that explain the process of disaster and the conceptual aspects that are aspects of literacy that is strongly related to disaster mitigation. As for the spread of students' literacy skills in aspects of the concept, it can be seen in table 3 .

As already discussed that in the process of disaster there are several scientific concepts that occur. Based on the spread of the students' answer, the dominant response considered that the flood disaster was only caused by the tide of sea water. Students state that the tidal floods affected by the high and low of land and the other students supported that throwing away garbage would affect the drains and become a driving factor for flooding. Mastery of the aspects of the disaster process of students indicates that it is still not comprehensive. It is shown that only 4 students were aware that tidal flood was caused by sea water, which was exacerbated due to the decrease in the surface of the sea due to land use change in coastal areas.

The results of the study on students' disaster mitigation literacy abilities in the aspects of the context and participants' attitudes are dictated by a different outcome with the research conducted by Soobard ${ }^{[22]}$ stating that students have difficulty when providing solutions and decisions on the tidal flooding problems are undertaken. The results of the research done by Soobard stated that learners have difficulty when giving attitudes and decided to solve the environmental tidal flooding problems presented. While in this study, the results indicate that learners can already formulate an attitude and solutions to solve the problem of tidal flooding 
in Semarang City. It is indicated by the high score of students' achievement in aspects of context and attitude

The disaster mitigation literacy of students are not only related to the tidal floods but also to other disasters as a whole. Generally, in Indonesia is a disaster-prone zone has become a necessity for learners to literate natural disasters. Learners should have a good knowledge of disaster mitigation.

\section{Conclusion}

Disaster mitigation literacy profile of students in the vulnerable area of tidal flooding Semarang city is still relatively low from the knowledge aspects of the process and concept while classified as being in the aspect of the context and expected attitude. The weak aspects of the process and concepts are based on the lack of discussion and teaching materials that contain the floods due to tides so that students lack material to gain knowledge about it.

Based on the results of this study, what can be done is to improve students' disaster mitigation literacy skills through several efforts such as the development of assessment forms that are oriented towards scientific literacy, development of teaching materials based on tidal flooding problems related to phenomena and designing learning with social science perspectives. The last hope of this research is to be able to make people and students aware of the importance of having disaster mitigation literacy for students around the environment and can reduce and anticipate the negative impacts that generated by the disaster.

The results of this study are also expected to be a solution in improving student disaster mitigation literacy by increasing access to learning related to the tidal flood disaster. This study can be used as a baseline to prepare learning and enrichment materials related to tidal flooding disaster in Semarang City. 


\section{References}

[1] Astuti, Sri. 2009. Reklamasi Tipologi Bangunan dan Kawasan Akibat Pengaruh Kenaikan Muka Air Laut di Kota Pantai Semarang.Departemen Kimpraswil.Bandung

[2] Eisenman, D. P., Cordasco, K. M., Asch, S., Golden, J. F., \& Glik, D. (2007). Disaster planning and risk communication with vulnerable communities: lessons from Hurricane Katrina. American Journal of Public Health, 97 Suppl 1, 109-115.

[3] Velasquez, G. T., Uitto, J., Wisner, B., \& Takahashi, S. (1999). A new approach to disaster mitigation and planning in megacities: The pivotal role of social vulnerability in disaster risk management. Cities and the environment: New approaches for ecosocieties, edited by Takashi Inoguchi, E. Newman, and G. Paoletto, 161, 184.

[4] Ramadhany, A.S, Anugroho, A.D.S, Subardjo, P. 2012. Daerah Rawan Genangan Rob di Wilayah Semarang.Journal Of Marine Research,Vol. 1 No. 2 hlm 174-180.

[5] Kristianti, S.A.R.Y, Ayu, R.. 2014. Kesiapsiagaan Komunitas Sekolah Dasar Terhadap Bencana Rob Di Kecamatan Sayung, Kabupaten Demak Tahun 2014 (Sebagai Bahan Pengayaan Pembelajaran Geografi Pada Materi Pokok Mitigasi dan Adaptasi Bencana Alam Kelas X). Jurnal FKIP UNS, Vol 3 No 1

[6] Ervin, Akhmad, Santoso, A.B, Juhadi. 2017. Pelaksanaan Program Siaga Bencana Di Sekolah Menengah Pertama Pada Kawasan Rawan Bencana.Jurnal Geografi, 5 (3) ISSN 2252-6684.

[7] Wright, L. H. (2012), Education in emergencies research methodologies: Identifying successes and gaps in the field. Paper presented at the annual meeting of the 56th Annual Conference of the Comparative and International Education Society, Caribe Hilton, San Juan, Puerto Rico, April 2012.

[8] Tomlinson, K., \& Benefield, P. (2005), Education and conflict: Research and research possibilities. United Kingdom: National Foundation for Educational Research.

[9] Alexander, D. (2007), Misconceptions as a Barrier to Teaching about Disasters. Prehospital and Disaster Medicine, Vol. 22, No. 2, pp. 95-103.

[10] Juhadi, J., Hidayah, I., \& Nugraha, S. B. (2018).Pendidikan Kebencanaan Untuk Anak Usia Dini Dengan Wahana Bermain Taman Eling-Waspada-Siaga (Ews). Jurnal Pengabdian Kepada Masyarakat, 24(2), 655-661.

[11] Maknun, J. (2017). Pembelajaran Mitigasi Bencana Berorientasi Kearifan Lokal pada Pelajaran IPA di Sekolah Menengah Kejuruan.ATIKAN, 5(2).

[12] Gultom, H.T, Juhadi, Aji, Ananto. 2018. Fenomena Banjir Rob di Kota Semarang Sebagai Sumber Belajar. Jurnal Geografi, 6(3) ISSN 2232-6684.

[13] Holbrook, J., Rannikmae, M. 2009. The Meaning of Scientific Literacy .International Journal of Environmental and Science Education, 4(3): 275-288

[14] Twigg, John. 2015. Disaster Risk Reduction. London: Overseas Development Institute.

[15] Selby D. \& Kagawa F. (2012), Disaster Risk Reduction in School Curricula: Case Studies from Thirty Countries. UNESCO, Paris/UNICEF Geneva. 2012. 207pp.

[16] Mangione, G. R., Capuano, N., Orciuoli, F., \& Ritrovato, P. (2013). Disaster Education: a narrative-based approach to support learning, motivation and students' engagement. Journal of e-Learning and Knowledge Society, 9(2).

[17] Marlyono, S.G, Pasya, G.K, dan nandi. 2016. Pengaruh literasi informasi bencana terhadap kesiapsiagaan masyarakat dalam menghadapi bencana di Propinsi Jawa Barat. Jurnal Pendidikan Geografi, vol. 16, no. 2, page.116-123. 
[18] Mahardika, E. A. S., Suwono, H., \& Indriwati, S.E. 2016. Eksplorasi Kemampuan Awal Literasi Biologi Siswa Kelas X SMAN 7 Malang. Prosiding Seminar Nasional Pendidikan Biologi dan SAINSTEK (SNBS,2016). Universitas Muhammadiyah Surakarta.Surakarta, 21 Mei 2016.

[19] Archer-Bradshaw, R. E. 2014. Demystifying Scientific Literacy: Charting The Path For The 21st Century.Journal of Educational and Sosial Research, 4(3): 165-172

[20] OECD (2017), PISA for Development Assessment and Analytical Framework: Reading, Mathematics and Science, Preliminary Version. OECD Publishing, Paris.

[21] Sugiyono. 2013. Metode Penelitian Kuantitatif, Kualitatif dan R\&D. Bandung: Alfabeta.

[22] Soobard.R. dan Rannikmae.M, “Assesing student's level of scientific literacy using interdisiplinary scenarios," Science Education International, vol. 22, no. 2, 2011.hal. 133-144. 